\title{
Faith-Based Organizations: A Potential Partner in Rural Transportation
}

\author{
Tom Seekins, Steve Bridges, Annesa Santa, Daniel J. Denis, \\ and Andrea Hartsell \\ University of Montana
}

\begin{abstract}
Disability advocates frequently suggest that faith-based organizations (FBO) may be potential providers of transportation for people with disabilities living in rural communities. We conducted a national survey of rural FBOs in the United States to explore their capacity and interest in being involved in local transportation. We randomly selected 716 FBOs located within 15 miles of a rural center for independent living. Forty percent $(N=288)$ of these responded to our mailed survey. Responding faith communities averaged 300 worshiping adults with an average of 9.5 percent being judged to have a significant disability. Overall, respondents indicated they were neither willing nor unwilling to become involved in providing transportation to either the general public or to people with disabilities. Nevertheless, 32 percent of respondents said they would be willing or very willing to do so. Respondents reported that their congregations owned a total of 146 vehicles, 18.5 percent of which were judged to be accessible. Results are discussed in terms of the need to understand faith communities and their orientation to community service.
\end{abstract}




\section{Introduction}

Some 12 million people, 41 percent of the U.S. rural population, live in counties with no public transportation (Rural Transit Assistance Program 1995; Community Transportation Association of America 1995) The lack of transportation in rural areas is one of the most significant and persistent problems reported by people with disabilities and those who serve them (Arcury, Preisser, Gesler, \& Powers 2005; Association of Programs for Rural Independent Living 2001; Jackson, Seekins, and Offner 1992; Gonzales, Seekins, and Kasnitz 2000; National Council on Disability 2005).

One contributing factor of the lack of rural transportation has been the inequitable allocation of resources to rural communities, with 95 percent of federal funds going to subsidize transportation for the 75 percent of the population living in cities and 5 percent going to support transportation for the 25 percent of the population living in rural areas (Seekins, Spas, and Hubbard 1999). While addressing this inequality directly through advocacy is an important step for improving transportation in rural communities (Association of Programs for Rural Independent Living 1999, 2001; Jeskey and Bush 2002; Zeilinger 2000), it is also important to develop methods and strategies that rural communities can use to deliver transportation services (Bernier and Seekins 1999; Seekins, Kasnitz, Gonzales, \& Stombaugh 2002).

In the ongoing debate about the lack of rural transportation, rural advocates, program planners, policy-makers, and people with disabilities often raise the possibility of turning to Faith-Based Organizations (FBO) for assistance (Association of Programs for Rural Independent Living 1999; Jeskey and Bush 2002). These advocates presume that many FBOs, if not most, own vehicles for transporting members and may be willing to provide basic transportation for people with disabilities.

Recently, national policy-makers have emphasized involving FBOs in human services (Chaves 1999; Montiel 2003). Indeed, Seekins, Enders, Pepper, \& Sticka, 2007, found that 10 percent of recipients of Section 5310 funding to provide transportation services to elderly and persons with disabilities were FBOs. Involving FBOs in providing human services is controversial, however (Eck 2001). Proponents argue that $\mathrm{FBO}$ are ubiquitous, and many have a service mission that could extend scarce social resources. Opponents express concerns about issues of the separation of church and state. Pragmatically, researchers also point out that several of 
the largest social service providers in the United States are FBOs and that they are among the largest recipients of federal funding.

Sider and Unruh (2004) note a lack of agreement on what constitutes an FBO. They describe the characteristics of six types of human service organizations, ranging from faith-permeated to secular programs. One major distinction involves the involvement of FBOs in services directly or through a separate organization.

Chaves (1999) reported findings from the National Congregation Study that used a hypernetwork procedure to generate a national random sample of congregations. He found that 57 percent of congregations have some social service project, but that only 11 percent reported receiving outside funds for those projects and only 3 percent received government funds for those projects. Chaves noted that, while 36 percent of congregations would apply for government funds to support social service projects, 15 percent had policies against doing so.

Chaves also found that very large congregations (more than 900 regularly-attending members) appeared far more willing to be involved in government-sponsored programs to provide social services. He noted that the median congregation has only 75 regular members and an annual budget of $\$ 55,000$, and suggests that substantial increases in delivery of social services by congregations can occur only through increases in government funding to do so.

In addition, Chaves reported that 64 percent of predominantly African-American congregations expressed willingness to apply for government funds compared with only 28 percent from predominantly white congregations. Further, he explained that liberal to moderate congregations are more willing to be involved in government programs than conservative or evangelical ones.

Little is known about the extent to which FBOs own vehicles, however, or about the extent to which they provide accessible community transportation. In a series of informal conversations with a variety of members from several faiths, not one reported that their church or synagogue owned a vehicle to transport even their own members. Conversely, we found that 10 percent of recipients of Section 5310 funds reported being FBOs (Seekins 2006).

Undoubtedly, many FBOs do own vehicles and do provide transportation at least to their members (many with disabilities). There may be a variety of barriers to these $\mathrm{FBOs}$ providing community transportation, however. These barriers are not yet clearly identified or understood. Given the frequent mention of FBOs as a potential solution to rural transportation concerns of people with disabilities 
(Jeskey and Bush, 2002) and the lack of information about FBOs, there is a need to explore the roles of these organizational resources in rural community transportation.

The purpose of this study was to assess the potential involvement of rural FBOs in providing community transportation (to work, recreation, etc.) for people with disabilities. To the authors' knowledge, this is the first national study of the role of churches in providing rural accessible transportation. As such, it is an exploratory study. The primary questions of interest included: What is the capacity and willingness of rural FBOs to provide accessible transportation? What are the barriers to their participation in community transit programs? We developed six main exploratory hypotheses to guide our analysis, including:

1. Faith communities (FCs) 1 in larger rural towns would have more members than those located in smaller communities but the proportion of members with disabilities would be equal across size.

2. Larger FCs would be more likely to own and operate vehicles.

3. The larger the FC, the more likely it is to operate programs that serve nonmembers.

4. The more control an FC exerts over a service program, the more likely that religion will be integrated into the service program.

5. The quality of public transportation will be rated lower by FCs in smaller rural towns.

6. Smaller FCs will report more barriers to service than larger ones.

\section{Method}

\section{Sample}

A large number of FBOs exist in the United States. The American Church List (2006) reports 365,312 churches in the United States with a phone-book listing. Of those, approximately 119,823 are located in nonmetropolitan counties. The largest denominations include Baptist (86,434 churches), Church of Christ (59,336 churches), Adventist (43,571 churches), Pentecostal (38,959 churches), Methodists (32,242 churches), Evangelical (25,847 churches), and Catholic (22,278 churches). Smaller groups include the Latter Day Saints (7,952 churches), Episcopal (7,116 churches), Jewish (2,871 synagogues), Metaphysical (2,434 churches), and a miscellaneous group with some 56,400 churches. Rothauge (1983) classi- 
fies congregations by size, including family churches that have 1-50 members; pastoral churches, 51-150 members; program churches, 151-350 members; and corporate churches, 351 or more members. This vast number and variety of FCs creates challenges in developing research samples (Chaves 1999).

Our data analysis plan suggested that the most stringent statistical test would involve an ANOVA with five factors each of region and religion. Assuming a relatively small effect size of .18 and adopting a significance level of .05 , we required 375 respondents for an acceptable level of power (.80). Estimating a 60 percent return rate, we selected a pool of 625 respondents to obtain the needed sample of 375.

We chose to survey congregational leaders. First, we surveyed 89 centers for independent living (CILs) located in nonmetropolitan counties and serving rural areas (Seekins 2006). Next, we used the online Yellow Pages to identify FBOs within a 15mile radius of the address of the main office of the 62 responding CILs. This yielded a listing of 3,334 FBOs. Two authors reviewed the list and eliminated duplicate addresses and entries that were not local congregations (regional administrative offices, training centers, etc.). This produced a list of 2,535 FBOs. Next, we listed the churches grouped by the respective 62 CILs that had responded to the previous survey. Two researchers then randomly selected up to 12 churches associated with each CIL. The researchers selected a sample of 716 churches.

\section{Procedures}

We conducted a series of interviews and focus groups with transportation experts, providers, and consumers to identify initial issues of importance. Next, we conducted a literature review to identify additional issues and data collection methods. Third, we drafted a survey questionnaire. Representatives of transportation networks and FBOs reviewed the draft instrument for content. Fourth, we conducted a "talk aloud" procedure in which four potential respondents (congregational leaders) from local FBOs read the survey aloud to the researchers and talked about their interpretation of the question and the meaning of their answers. We revised the survey instrument and instructions accordingly.

The final questionnaire included six questions about the demographics of a congregation (title of respondent, religious foundation, number of worshiping adults, etc.), two questions about the general orientation of the congregation to community outreach activities designed to help classify the congregation using the Sider and Unruh (2004) typology, eight questions about transportation issues 
(number of vehicles, quality of local transportation), two questions about barriers to conducting transit programs, and an open-ended question about their general views of these issues.

We conducted a small pilot test with $20 \mathrm{FBO}$ selected from the area of the CIL located in the smallest metropolitan area to compare phone versus mail-based survey procedures. We found that making a connection with respondents by phone was very difficult and time consuming, and produced few responses compared to the mailed survey.

We used Dillman's (2000) mail survey procedures. First, we mailed a postcard to the congregational leader of each selected FBO that briefly described the study, how they were selected as a respondent, and explained that they would receive a survey in the mail within two weeks. Next, we mailed survey packets to the 716 selected respondents. Each survey packet included a letter that concisely outlined the study's purpose and reiterated how the respondent was selected. In addition, the packet included a four-page bifolded questionnaire and a self-addressed return envelope.

In response to our first mailing, we received 290 returned surveys; 169 completed and 33 uncompleted. ${ }^{2}$ Eighty-eight (12.3\%) were returned undeliverable. One month after the initial mailing, we mailed a second survey packet to the 426 nonrespondents and received an additional 86 completed surveys. Of those 86,75 were completed and 11 were uncompleted.

\section{Data Analysis Methods}

We used descriptive statistics to explore the demographics, capacity, and involvement of respondents. We used tests of correlation to examine the relationships between size of congregation and involvement, and similar questions. We employed ANOVA to examine differences in capacity and interest by region, faith, and denomination.

\section{Results}

We received a total of 288 of $716(40 \%)$ randomly selected respondents. An additional 88 were returned as undeliverable, for an effective response rate of 45.8 percent. Of the 288 returned surveys, 244 (84.7\%) were completed and 44 (15.3\%) were uncompleted. Forty-five responses (19\%) were from rural towns of less than 2,500, 59 (25\%) from small towns of 2,500 to 10,000 , and 137 (57\%) from larger 
towns of 10,000 to 50,000 . Most (98.4\%) respondents reported their faith community was based on Christianity.

Table 1 presents membership of FCs responding to the survey across both Rothauge's typology and geography. The average number of worshiping adults across FCs was 299.5, with a median of 100 and a range of 6 to 5,000. The mean number of worshiping adults with significant disability was estimated to be 19.5 (9.5\%) with a median of 7.5. Larger FCs had more members $\left(\chi^{2}(6, N=230)=21.42\right.$, $p=.002)$ but did not have a greater proportion of members with disabilities $\chi^{2}(2$, $N=234)=4.67, p=.097$. However, there is a significant trend for smaller FCs to have more members with disabilities $r(225)=-.201, p=.002$.

\section{Table 1. Church Membership by Rothauge's Typology Across Rural Categories}

\begin{tabular}{lcccc}
\hline & $\begin{array}{c}\text { Rural Town } \\
(\mathbf{2 , 5 0 0} \text { or less) }\end{array}$ & $\begin{array}{c}\text { Small Town } \\
(2,500-10,000)\end{array}$ & $\begin{array}{c}\text { Large Town } \\
(\mathbf{1 0 , 0 0 0 - 5 0 , 0 0 0 )}\end{array}$ & Total \\
\hline $\begin{array}{l}\text { Family church } \\
(1-50)\end{array}$ & $16(7 \%)$ & $17(7.4 \%)$ & $29(12.6 \%)$ & $62(27 \%)$ \\
$\begin{array}{l}\text { Pastoral church } \\
(51-150)\end{array}$ & $22(9.6 \%)$ & $24(10.4 \%)$ & $37(16.1 \%)$ & $83(36.1 \%)$ \\
$\begin{array}{l}\text { Program church } \\
(151-350)\end{array}$ & $5(2.2 \%)$ & $9(3.9 \%)$ & $27(11.7 \%)$ & $41(17.8 \%)$ \\
$\begin{array}{l}\text { Corporate } \\
\text { church }(351 \text { or } \\
\text { more })\end{array}$ & $2(1 \%)$ & $6(2.6 \%)$ & $36(15.7 \%)$ & $44(19.1 \%)$ \\
Total & $45(19.6 \%)$ & $56(24.3 \%)$ & $129(56.1 \%)$ & $230(100 \%)$ \\
\hline
\end{tabular}

About a third of the respondents indicated that their FC owned one or more vehicles. Seventy-four respondents reported owning a total of 146 vehicles, of which 27 (18.5\%) were reported to be equipped with a lift or ramp that could transport people who use wheelchairs, scooters, or other mobility devices.

Of those that owned vehicles, most owned very few. Accordingly, we recoded the data to reflect whether an FC owned one or more vehicles or did not own a vehicle. Table 2 presents vehicle ownership across Rothauge's typology. We did not find statistical evidence of a difference in ownership between the different types of FCs.

The more vehicles an FC reported owning, the more likely they were to report operating accessible vehicles $\left.\chi^{2}(1, N=177)=10.21, p=.001\right)$. Similarly, as the size 
of the geographic area served increased, the number of vehicles reported being owned increased $\chi^{2}(2, N=224) 8.03, p=.018$; as did the number of accessible vehicles $\chi^{2}(2, N=179) 7.58, p=.023$. The distribution of the number of vehicles owned, however, is skewed toward the low end and limits the ability to generalize these findings.

\section{Table 2. Vehicle Ownership by FCs Across Rothauge's Typology}

\begin{tabular}{lccc}
\hline & $\begin{array}{c}\text { Do Not Own } \\
\text { Vehicle }\end{array}$ & $\begin{array}{c}\text { Own One or More } \\
\text { Vehicles }\end{array}$ & Total \\
\hline Family church (1-50) & $46(21.4 \%)$ & $13(6 \%)$ & $59(27.4 \%)$ \\
$\begin{array}{l}\text { Pastoral church } \\
(51-150)\end{array}$ & $49(22.8 \%)$ & $26(12.1 \%)$ & $75(34.9 \%)$ \\
$\begin{array}{l}\text { Program church (151-350) } \\
\begin{array}{l}\text { Corporate church (351 or } \\
\text { more) }\end{array}\end{array}$ & $26(12.1 \%)$ & $14(6.5 \%)$ & $40(18.6 \%)$ \\
& $23(10.7 \%)$ & $18(8.4 \%)$ & $41(19.1 \%)$ \\
Total & $144(67 \%)$ & $71(33 \%)$ & \\
\hline
\end{tabular}

We asked whether the respondent provided any outreach programs to community residents who were not members of the church and whether they provided transportation to members. A total of $133(55.2 \%)$ respondents reported that they provided outreach programs to nonmembers, and 132 (55.2\%) reported providing transportation to members. More FCs reported providing transportation to their members than reported owning vehicles. Anecdotally, several respondents reported organizing volunteers informally to provide rides to other members. There was no statistical evidence of differences between churches across the size of the geography served $\chi^{2}(2, N=238)=3.771, p=.152$. Larger FCs were, however, more likely to provide outreach programs $\chi^{2}(3, N=230)=14.71, p=.002$. Table 3 portrays the provision of outreach services across Rothauge's typology. In essence, the size of the $\mathrm{FC}$ is more important in the provision of outreach services than the size of the community served. 


\section{Table 3. Provision of Outreach Programs to Nonmembers Across Rothauge's Typology}

\begin{tabular}{lccc}
\hline & $\begin{array}{c}\text { Do Not Provide } \\
\text { Outreach }\end{array}$ & $\begin{array}{c}\text { Provide Outreach } \\
\text { to Nonmembers }\end{array}$ & Total \\
\hline Family church (1-50) & $39(63 \%)$ & $23(37 \%)$ & $62(100 \%)$ \\
$\begin{array}{l}\text { Pastoral church } \\
(51-150)\end{array}$ & $37(45 \%)$ & $45(55 \%)$ & $82(100 \%)$ \\
$\begin{array}{l}\text { Program church (151-350) } \\
\begin{array}{l}\text { Corporate church (351 or } \\
\text { more) }\end{array}\end{array}$ & $14(34 \%)$ & $27(66 \%)$ & $41(100 \%)$ \\
Total and average & $13(29 \%)$ & $32(71 \%)$ & $45(100 \%)$ \\
\hline
\end{tabular}

For those who reported operating any community outreach programs that provided social services to local members who were not members of their FC, we asked how much the FC controlled those service programs and activities, and how much religious content was integrated into those community service activities. The more control exerted by the FC, the more likely religious content was integrated into the services $r(131)=.344, p=.000$.

We also asked a series of questions about the quality of public transportation for the general public and for people with disabilities in the area served by the FC. On average, respondents rated the quality of public transportation as 1.47 on a 5 -point scale, where 0 was poor and 4 was excellent. Respondents rated transportation for people with disabilities as 1.58 on a similar scale. Respondents in smaller rural communities rated the quality of transportation for the general public lower than respondents from larger communities $\left(\chi^{2}(4, N=237)=16.28, p=.003\right)$, but there was not a significant difference in the rating of the quality of transportation for people with disabilities across communities of different sizes. Table 4 summarizes those ratings across rural geography.

Respondents were asked to rate the willingness of their FC to become involved in providing transportation to people with disabilities and to the general public who lack their own means of transportation on a 5-point scale, where 0 was not willing and 4 was very willing. Overall, respondents indicated that they were neither willing nor unwilling to become involved in providing transportation to people with disabilities (an average rating of 1.96) or the general public (an average of 1.47 on 


\section{Table 4. Rating of Quality of Transportation for the General Public and People with Disabilities}

\begin{tabular}{lcc}
\hline & $\begin{array}{l}\text { Average Rating of } \\
\text { Quality of Public } \\
\text { Transportation for } \\
\text { General Public }\end{array}$ & $\begin{array}{l}\text { Average Rating of } \\
\text { Quality of Public } \\
\text { Transportation for } \\
\text { People with } \\
\text { Disabilities }\end{array}$ \\
\hline $\begin{array}{l}\text { Rural town of } \\
\text { 2,500 or less }\end{array}$ & .95 & 1.16 \\
Small town of & 1.44 & 1.54 \\
$2,500-10,000$ & 1.66 & 1.73 \\
Large town of & & \\
10,000-50,000 & 1.47 & 1.58 \\
Overall & & \\
\hline
\end{tabular}

Ratings ranged from 0-4, where 0 equaled poor and 4 equaled excellent.

a similar scale). Nevertheless, 32 percent of respondents said they would be willing or very willing to become involved in providing transportation to people with disabilities, and 19 percent responded affirmatively about the general public.

We received an average of 4.2 responses from $\mathrm{FBOs}$ for each of $57 \mathrm{CIL}$ service areas, ranging from $3 \mathrm{CIL}$ service areas for which there was 1 responding $\mathrm{FBO}$ to 2 for which there were 8. No FBOs submitted responses for $5 \mathrm{CIL}$ service areas. The rating of the quality of public transportation for all individuals and for people with disabilities by CILs average .9 and .8 , respectively, on a 5-point scale where 0 was poor and 4 was excellent. We examined the relationship between ratings of the quality of public transportation for all people and for people with disabilities by the CILs and the FBOs in the same area. First, we calculated average ratings for the FBOs associated with each CIL. Next, we conducted a Spearman correlation of these ratings between CILs and FBOs. There was not a statistically significant correlation of ratings between these two groups.

We expected that FBOs might face several barriers to providing transportation to people with disabilities who are not members of their church. Table 5 presents the distribution of the barriers reported by respondents across Rothauge's categories of size. We conducted an analysis of variance to examine the sum of these barriers and found no significance $F(3,221)=2.530, p,=.058$. Similarly, Table 6 presents 
the supports respondents indicated that they needed to be in place in order to become involved in local transportation.

\section{Table 5. Barriers to Involvement in Providing Transportation by Rothauge's Typology}

\begin{tabular}{|c|c|c|c|c|c|c|c|c|}
\hline & $\begin{array}{l}\text { Not in } \\
\text { Mission }\end{array}$ & Liability & Stretch & $\begin{array}{l}\text { Lack } \\
\text { Skills }\end{array}$ & $\begin{array}{l}\text { Lack } \\
\text { Staff }\end{array}$ & $\begin{array}{c}\text { Lack } \\
\text { Money }\end{array}$ & Gvmt. & $\begin{array}{l}\text { Church } \\
\text { Policy }\end{array}$ \\
\hline $\begin{array}{l}\text { Family church } \\
(1-50)\end{array}$ & $\begin{array}{c}19 \\
(37.1 \%)\end{array}$ & $\begin{array}{c}36 \\
(60.0 \%)\end{array}$ & $\begin{array}{r}33 \\
(55.0 \%)\end{array}$ & $\begin{array}{r}30 \\
(50 \%)\end{array}$ & $\begin{array}{r}50 \\
(83.3 \%)\end{array}$ & $\begin{array}{r}55 \\
(91.7 \%)\end{array}$ & $\begin{array}{r}24 \\
(40.0 \%)\end{array}$ & $\begin{array}{r}5 \\
(8.3 \%)\end{array}$ \\
\hline $\begin{array}{l}\text { Pastol } \\
(51-1\end{array}$ & $\begin{array}{r}33 \\
(40.7 \%)\end{array}$ & $\begin{array}{r}46 \\
(56.8 \%)\end{array}$ & $\begin{array}{r}47 \\
(58.0 \%)\end{array}$ & $\begin{array}{r}47 \\
(58.0 \%)\end{array}$ & $\begin{array}{r}62 \\
(76.5 \%\end{array}$ & $\begin{array}{r}74 \\
(91.4 \%)\end{array}$ & $\begin{array}{r}30 \\
(37.0 \%)\end{array}$ & $\begin{array}{r}5 \\
(6.2 \%)\end{array}$ \\
\hline & $\begin{array}{r}19 \\
(39.0 \%)\end{array}$ & $\begin{array}{r}18 \\
(43.9 \%)\end{array}$ & $\begin{array}{r}21 \\
(51.2 \%)\end{array}$ & $\begin{array}{r}20 \\
(48.8 \%)\end{array}$ & $\begin{array}{r}30 \\
(73.2 \%)\end{array}$ & $\begin{array}{r}35 \\
(85.4 \%)\end{array}$ & $\begin{array}{r}10 \\
(24.4 \%)\end{array}$ & $\begin{array}{r}2 \\
(4.9 \%)\end{array}$ \\
\hline $\begin{array}{l}\text { Corporate } \\
\text { church ( } 351 \text { or } \\
\text { more) }\end{array}$ & $\begin{array}{r}17 \\
(39.5 \%)\end{array}$ & $\begin{array}{r}20 \\
(46.5 \%)\end{array}$ & $\begin{array}{r}13 \\
(30.2 \%)\end{array}$ & $\begin{array}{r}18 \\
(41.9 \%)\end{array}$ & $\begin{array}{r}28 \\
(65.1 \%)\end{array}$ & $\begin{array}{r}34 \\
(79.1 \%)\end{array}$ & $\begin{array}{r}14 \\
(32.6 \%)\end{array}$ & $\begin{array}{r}3 \\
(7.0 \%)\end{array}$ \\
\hline Overall & $\begin{array}{r}91 \\
(38.4 \%)\end{array}$ & $\begin{array}{r}127 \\
(53.6 \%)\end{array}$ & $\begin{array}{r}117 \\
(49.4 \%)\end{array}$ & $\begin{array}{r}121 \\
(51.1 \%)\end{array}$ & $\begin{array}{r}178 \\
(75.1 \%)\end{array}$ & $\begin{array}{r}207 \\
(87.3 \%)\end{array}$ & $\begin{array}{r}81 \\
(34.2 \%)\end{array}$ & $\begin{array}{r}16 \\
(6.8 \%)\end{array}$ \\
\hline
\end{tabular}

Table 6. Requirements for Becoming Involved in Providing Transportation by Rothauge's Typology OR Rural Categories

\begin{tabular}{lrrrr}
\hline & $\begin{array}{c}\text { Council } \\
\text { Approval }\end{array}$ & Funding & $\begin{array}{c}\text { Freedom from } \\
\text { Interference }\end{array}$ & $\begin{array}{c}\text { Inter- } \\
\text { denominational } \\
\text { Sponsor }\end{array}$ \\
\hline $\begin{array}{l}\text { Family church } \\
(1-50)\end{array}$ & 25 & 38 & 22 & 10 \\
$\begin{array}{l}\text { Pastoral church } \\
(51-150)\end{array}$ & $43 \%)$ & $(63.3 \%)$ & $(36.7 \%)$ & $(16.7 \%)$ \\
& $(53.8 \%)$ & $(77.5 \%)$ & $(40.0 \%)$ & $(23.8 \%)$ \\
$\begin{array}{l}\text { Program church } \\
(151-350)\end{array}$ & & & & 19 \\
& $(51.2 \%)$ & $(73.2 \%)$ & $(39.0 \%)$ & $(22.0 \%)$ \\
$\begin{array}{l}\text { Corporate } \\
\text { church (351 or }\end{array}$ & & & & 9 \\
more) & $(61.4 \%)$ & $(86.4 \%)$ & $(25 \%)$ & $(31.8 \%)$ \\
$\begin{array}{l}\text { Overall } \\
\text { (15) }\end{array}$ & 121 & 175 & 83 & 14 \\
& $(51.1 \%)$ & $(73.8 \%)$ & $(35 \%)$ & $(22.8 \%)$ \\
\hline
\end{tabular}




\section{Discussion}

This study reports on the findings of a national survey of rural FBOs. We found that respondents rated the quality of public transportation in their communities as poor to adequate, a relatively comparable assessment to those made by the CILs serving the same areas. About one third of the respondents were either willing or very willing to become involved in providing transportation to people with disabilities who were not members of their congregation. However, the data indicate that these rural congregations owned few vehicles, and that a very small proportion of those were equipped with lifts or ramps that would permit a person who used a wheelchair or scooter to ride.

We found that FBOs in larger communities tended to have more members than those in smaller communities. The data showed a trend toward a significant difference in the proportion of worshiping members who were judged to have signifcant disabilities, with rural congregations tending to have a slightly higher proportion. This is consistent with the overall demographics of people with disabilities.

We found that larger FBOs were more likely to own and operate vehicles and that those with more vehicles did tend to have more accessible vehicles. There were not statistical differences in the rate of ownership between FBOs in larger and smaller communities; rather, the key variable in ownership appears to be the size of the congregation.

Our analysis showed that the larger the FC, the more likely it was to operate community service programs that served nonmembers. As with vehicle ownership, however, the size of the community did not predict the likelihood of serving the community. Again, the size of the congregation appears to affect the likelihood of providing outreach services to nonmembers.

For those respondents who reported operating an outreach program that provided services to nonmembers, we asked a series of questions about the degree of integration of religion into those services. Our data showed that the more programmatic and financial control exerted over the outreach program by the FC, the more likely religious content was to be integrated into the community service activities.

Finally, FBOs reported that the major barriers facing them in any effort to become involved in providing transportation to people with disabilities in their communities were the lack of financial resources to do so, lack of staff to manage or provide such services, concerns about liability, lack of skills and knowledge about disability 
and transportation issues, and concerns that such involvement would stretch the time commitments of the congregation. Only about a third of respondents indicated that it was simply not in their mission or that they were concerned about becoming entangled in government programs.

Similarly, respondents indicated that the most significant requirement for their involvement was financial resources. Just over half reported that they would need their council's approval. One third reported that they would need assurances of avoiding government interference in their church. Finally, some indicated that they would only participate if the program was part of an interdenominational effort.

One limitation of the study reflects potential response bias. Several surveys were returned uncompleted with comments that the respondent judged completing such surveys as a distraction from their duty to promote spiritual development and worship. This position reflects an internal orientation in which the sole duty of worship is spiritual development-as opposed to a social gospel orientation in which good works are encouraged as an expression of worship (Chaves 1999). It is possible that many nonrespondents who hold similar beliefs did not even bother to return an uncompleted survey. As such, the results of this survey may represent a bias to congregations with a social gospel foundation and not all congregations.

This observation points to the importance for disability advocates and community planners to understand the orientation and limitation of FCs before approaching them for support in providing community services. While any congregation leader can be approached about becoming involved, their reactions may differ significantly. Some FCs - those that are larger and those with a more liberal theology-are likely to have greater capacity or be more interested. Others FCs-those that are smaller or those with a more fundamental theology-are likely to face more limitations to becoming involved or be less interested in secular activity. Careful consideration of these factors can reduce the likelihood of misunderstandings and frustration.

Another limitation to this study is that it surveyed only rural FBOs operating within the service area of a CIL located in a nonmetropolitan county. While this allowed for a sample of FBOs to compare to the CIL respondents from a previous study and provided a sample framework, it may also reflect an economic and geographic bias based on the locations of those CILs. Moreover, it focuses only on rural communities. There is no comparison to FBOs in larger, metropolitan areas. 
FBOs are an important element in nearly every rural community. Given that many people in rural communities are in desperate need of transportation and left literally praying for a ride, it is only natural that rural residents turn to those who may feel a religious duty to serve their fellows. These data will contribute to understanding the potential for FBOs to contribute to solving the rural accessible transportation problem and the limitations they face in doing so. This research may also point to best-practice models for FBO involvement in responding to disability and the national conversation about the role of FBOs in providing public services.

\section{Acknowledgements}

This research was supported by a grant from the National Institute on Disability and Rehabilitation Research, U.S. Department of Education (H133B030501). The authors would like to acknowledge the helpful direction of Peter Shober, pastor of the Congregational Church of Missoula, for his guidance in shaping the survey content and procedures. We also wish to acknowledge the assistance of Health Kirby in the early development of the project. In addition, we also thank our colleagues Catherine Ipsen, Nancy Arnold, Alexandra Enders, and Donna Bainbridge for their helpful comments.

\section{Endnotes}

1 Focus group participants suggested we use the term "faith community" to embrace a broader array of arrangements than is captured by the terms church or congregation. We use all relevant terms in this report, as appropriate.

${ }^{2}$ We asked respondents to return the survey in the self-addressed return envelope even if they did not complete it so that we would not contact them about it again.

\section{References}

American Church List. 2006. Retrieved October 3, 2006 from http://www.americanchurchlist.com.

Arcury, T. A., J. S. Preisser, W. M. Gesler, and J. M Powers. 2005. Access to transportation and health care utilization in a rural region. The Journal of Rural Health 21 (1), 31-38. 
Association of Programs for Rural Independent Living. 1999. Taking on rural transportation. Retrieved September 5, 2002 from http://april.umt.edu/Taking. htm.

Association of Programs for Rural Independent Living. 2001. Rural transportation for people with disabilities: Transportation Equity Act of the 21st Century (TEA 21) 2003 re-authorization [Rural Policy Brief]. Kent, OH: Association of Programs for Rural Independent Living.

Bernier, B., and T. Seekins. 1999. Rural transportation voucher program for people with disabilities: Three case studies. Journal of Transportation and Statistics 2: 61-70.

Chaves, M. 1999. Religious congregations and welfare reform: Who will take advantage of "Charitable Choice?" American Sociological Review 64: 836-846.

Community Transportation Association of America. 1995. Atlas of public transportation in rural America, 1994. Washington, DC: Community Transportation Association of America.

Dillman, D. A. 2000. Mail and electronic surveys: The tailored design method, 2nd ed. New York: John Wiley \& Sons.

Eck, D. L. 2001. A new religious America: How a "Christian country" has now become the world's most religiously diverse nation. San Francisco: Harper Collins.

Gonzales, L., T. Seekins, and D. Kasnitz. 2000. Taking on rural transportation. Common Threads, 13-15. Missoula, MT: Montana University Affiliated Rural Institute on Disabilities.

Jackson, K., T. Seekins, and R. Offner. 1992. Involving consumers and service providers in shaping rural rehabilitation agenda. American Rehabilitation 18(1), 23-29, 48.

Jeskey, C., and M. Bush. 2002. Our role in the process: A grassroots guide to building community-based employment transportation. Washington, DC: Community Transportation Association of America.

Montiel, L.M. (2003). The use of public funds for delivery of faith-based human services: A review of the literature focusing on the public funding faith-based organizations in the delivery of social services, 2nd ed. The Roundtable on Religion and Social Welfare Policy, retrieved May 21, 2007 from http://www. religionandsocialpolicy.org/publications/publication.cfm?id=14. 
National Council on Disability. 2005. The current state of transportation for people with disabilities in the United States. Washington, DC: National Council on Disability.

Rothauge, A. 1983. Sizing up a new congregation for new member ministry. NY: Episcopal Church Center.

Rural Transit Assistance Program. 1995. Atlas of public transportation in rural America. Washington, DC.

Seekins, T. 2006. Faith based organizations and rural transportation: Research progress report \#32. Missoula, MT: Research and Training Center on Disability in Rural Communities, Rural Institute on disabilities, The University of Montana.

Seekins, T. A. Enders, A. Pepper, and S. Sticka. 2007. Allocation and use of section 5310 funds in Urban and Rural America. Journal of Public Transportation 10: 81-101.

Seekins, T., D. Kasnitz, L. Gonzales, and D. Stombaugh. 2002. The Traveler's Cheque program: Making transportation work for people with disabilities in rural areas. Kent, $\mathrm{OH}$ : Association of Programs for Rural Independent Living.

Seekins, T., D. Spas, and M. Hubbard. 1999. Inequities in rural transportation (Ruralfacts). Missoula, MT: RTC: Rural.

Sider, R. J., and H. R. Unruh. 2004. Typology of religious characteristics of social service and educational organizations and programs. Nonprofit and Voluntary Sector Quarterly 33 (1): 109-134.

Zeilinger, C. 2000. What is equity anyway: Take another look at an issue we all know well. Community Transportation (March/April): 10-11, 33-34, 39-41.

\section{About the Authors}

TOM SEEkINS (ruraldoc@ruralinstitute.umt.edu) is a professor of psychology and director of the Research and Training Center on Disability in Rural Communities at the University of Montana.

STEVE BRIDGeS (bridges@ruralinstitute.umt.edu) is a graduate student in the Department of Sociology at the University of Montana. His interests are in the area of social movements. 
ANNESA SANTA (annesasanta@gmail.com) is a graduate student in the Department of Psychology at the University of Montana. Her interests are in the area of health psychology.

DANIEL J. Denis (daniel.denis@umontana.edu) is a professor of psychology at the University of Montana. He is particularly interested in statistical consulting.

ANDREA HARTSELl (ahartsell@ssttx.org) was a graduate student in the Department of Psychology at the University of Montana. 